\title{
Nyi Pohaci Sang Hyang Sri value in leader perspective of Cipatat Kolot Customary Societies
}

\author{
Bahagia Bahagia* 1, Bambang Hudayana ${ }^{2}$, Rimun Wibowo ${ }^{3}$, Zulkifli Rangkuti ${ }^{3}$ \\ ${ }^{1}$ Universitas Ibn Khaldun Bogor. \\ Jl. Sholeh Iskandar, Kedungbadak, Tanah Sereal, Bogor, Jawa Barat 16162, Indonesia. \\ ${ }^{2}$ Universitas Gadjah Mada. \\ Jl. Bulaksumur, Bulaksumur, Depok, Sleman, Yogyakarta 565223 \\ ${ }^{3}$ Sekolah Tinggi Manajemen IMMI Jakarta \\ Jl. Raya Tanjung Barat No. 11, Pasar Minggu, Jakarta Selatan, D.K.I. Jakarta 12530 \\ * Corresponding Author. E-mail: bahagiagia59@yahoo.co.id
}

\section{ARTICLE INFO}

Article History

Received:

7 March 2021;

Revised:

18 March 2021;

Accepted:

25 March 2021;

Available Online:

10 May 2021

\section{Keywords}

Agriculture;

Cipatat Kolot;

Indigenous;

Environment;

Nyi Pohaci;

Nature;

Rice

\begin{abstract}
This research aims to investigate Nyi Pohaci Sang Hyang Asri's value in Cipatat Kolot societies perspective. The research method uses an ethnographic qualitative approach. This method is implemented because this research is linked to the social community. To gather data was used as an indepth interview. Sample are selected through purposive technique. The result is probed meticulously through triangulation technique and triangulation sources. The result shows Nyi Pohaci Sang Hyang Asri is a customary society's faith. However, it becomes tradition and culture because the value of Nyi Pohaci pursues until nowadays generation. It has been embedded in their perspective. They must continue this perspective because it is mandatory from their forefather. While Nyi Pohaci release in proverb as non-material culture fro pursuing behavior in daily life. The other is Nyi Pohaci through traditional proverb which proverb has numerous meaning including they believe humans are in Nyi Pohaci and Nyi Pohaci are in human bodies. All parts of the human body, starting from human bones, human intellect, human flesh, human form, the hair on human bodies, bile in human stomachs, human minds and minds are formed by eating rice as Nyi Pohaci. As a result, the human dislike to ravage nature environment because Sri has been cultivated on the land's surface. As land and nature are damaged, they have devastated Sri as paddies. It indicates that a human has influenced Nyi Pohaci belief must protect the natural environment. The other is they adjust their behavior not to adopt fully an-organic agriculture. They try to use composting and fertilizer for livestock manure. As a consequence, the soil can be preserved from damaged and combat global warming like climate change.
\end{abstract}

This is an open access article under the $\mathrm{CC}-\mathrm{BY}-\mathrm{SA}$ license.

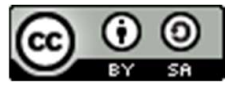

How to cite:

Bahagia, B., Hudayana, B., Wibowo, R., \& Rangkuti, Z. (2021). Nyi Pohaci Sang Hyang Sri value in leader perspective of Capitat Kolot Customary Societies. Harmoni Sosial: Jurnal Pendidikan IPS, 8(1), 1-12. https://doi.org/10.21831/hsjpi.v8i1.39241

\section{INTRODUCTION}

Myth is often also referred to as mythology, which is defined as a study about the myth. It can also be interpreted as the set or collection of various myths. In a broader sense, the term " myth " can refer to traditional stories, legends, and folklore (Yunarti \& Rahmadani, 2017). Myth is a kind of delusion or superstition resulting from modern human ignorance of distant human behavior previous. 
This gives rise to a conjecture in people's minds then turned into a deeply held trust together (Ihsan, 2019). In Sundanese literature, Dewi Sri, or renowned as Nyi Pohaci Sang Hyang Sri, is connected to the myth of rice's origin (Hertanto, 2013). Nyi Pohaci is ais a rice symbol. Customary societies respect nyi Pohaci because Nyi Pohaci deems giver livelihood like paddies as a staple food (Rohmana \& Ernawati, 2014). Even the Dewi Sri is worshipped by the farmer (Heryana, 2012). Nyi Pohaci is also recognized as the goddess of fertility and wealth (Mudiyono \& Wasino, 2015). It is connected to tradition and culture in agriculture through mythology and legend, including Beru Dayang (Batak), Isharo (Toraja), Dewi Pretiwi (Bali), Dewi Sri (Java), and Pohaci (Sunda) have built a faith system and religion (Kusdiwanggo \& Pamungkas, 2017).

Its impacts human perspective and belief. This shows that the myth has been adopted in human thinking as truth. Meaning that tale has a severe linkage to the faith of community or society despite the fact that it is not true, but the last story handed down to the generation can reach a made-up story as their behavior because they still receive the message. A society like this illustrates myths are considered definite truths and inviolable. The community is considered capable of giving an orientation to life and life in the world (Jatnika, 2018). Hermawan (2016) remarks that people think of a myth as a story that happened. Even more so, a story, for this society, is more valuable than material possessions. For this society, myths or "stories that are considered true" are very sacred, exemplary, and have a very important meaning. In general, there are numerous roles of myth, including explaining the environment they confront, as guidance inside the group to strengthen social loyalty among members in the group. As a result, they can differ from others and other groups, As effective education media especially for encouraging and embedded cultural value, belief, and social value (Iswidayanti, 2007).

Besides, the myth has another role, like it is connected to the truth of humanity. It can be as guidance to organize their daily activity and human activity (Angeline, 2015). It must be encouraged the myth can be depicted as character education such as willing to die for the shake of self-esteem, a persistent person, and open to other people. It can be bolstered by the education value of myth, social, mystical, entertainment, culture, and social identity (Margaretha, 2017). In another location, like in Tebo regency Jambi province, there is penganan myth. In this myth, the people convince that when some sorts of cake such as ketupat, pemangam, and sepang hang in the house ceiling, more guest in the environment visits that house (Yusanti, 2019). In another region like in Bangka Belitung, the societies recognize "kaapunan". In this myth, the person may not be presumptuous, don't talk orally and openly as well as may not rebuff. People who perform this prohibition believe that individuals can accept catastrophe and another calamity (Alfarisi et al., 2019). The effect is myths have been a part of human life; in Baduy, they perceive that life comes from God, and Dewi Sri renders the prosperity as a form of a symbol that Baduy homage (Nadroh, 2018).

Wahyuni (2019) reveals the literacy value of Dewi Sri, including Dewi Sri, portray as land or soil which as a mother who born crop which is useful for human and Dewi Sri is friendly media and favorable for increasing the literate ability in ecology as glue life harmony between human and human as well as natural environment as a place for life. Also, in some tribe like in Baduy societies, they believe that some activity including related to agriculture, cooking rice, alert paddies to rice through utilizing mortar must be performed by women as well as washing rice because it is linked to norm value to Nyi Pohaci (Suryani, 2014). Hermawan (2013) said that at the same time, as an attempt to raise awareness, human life is one with nature and a tribute to the Goddess Sri, rice's protector. Nyi Pohaci also has relations with women in customary societies' beliefs. The belief about Nyi Pohaci influences the existence of rituals in some customary societies. In Banceuy societies, they held the Mapag Dewi Sri ritual. This ritual has been pursued nowadays by the previous generation. Mapag Dewi Sri has meant that societies pick up Dewi Sri before they gathering paddies.

They respect Dewi Sri because they trust that Dewi Seri have rendered prosperity to them. There is some objective of this ritual including express gratitude to God for bestowing abundant of paddies yield, conserving tradition and culture in customary societies, and make human save balances and preserve the environment as well as express appreciation to their for father who has a big contribution to sustainable life (Rohmana \& Ernawati, 2014). Another function of Myt can conserve ecologies such as forest, water, oxygen, watery ecosystem, and soil fertility. Even salvage several species like fish and some wild creature. In Lumajang, the societies have renowned about Bamboo 
Forest where there is fond as spring water sources in the middle the forest. Every person convinces that as the person brave to gather fish from that fond, they receive life perturbances like calamity (Wulansari \& Nur, 2018).

From this theory, the function of myth can educate a person from the story, and the people believe that despite it is an untrue story. At least there is some value of myth such as social. The myth can overcome the social problem and protect and save the environment, especially for water, soil, forest, and animals. In this research will not try to discover again the research content which some researcher has performed. The research data is conducted in Cipatat Kolot societies in Bogor, West Java, where the community is a customary society. There is some objective of this research including it discovers about the connection of paddies and Nyi Pohaci in human both body and soul and the relation of human and environment based on the traditional proverb. Then, research will find out about the belief in Nyi Pohaci refer to conservation and organic agriculture toward agriculturefriendly ecology. Lastly, to find about the connection between culture and tradition to Nyi Pohaci belief.

\section{METHOD}

This research on Nyi Pohaci Sang Hyang Sri Value in Leader perspective of Cipatat Kolot Customary Societies, West Java, uses ethnography with a qualitative approach method. The research subjects are the indigenous people of Cipatat Kolot, Sukajaya District, Bogor Regency, West Java, Indonesia. The study uses qualitative with an ethnographic approach. Ethnography is a form of applied and pragmatic ethnography that explores certain social phenomena such as those that occur in everyday life (Bikker et al., 2017). Ethnographic qualitative studies are usually carried out to describe a group's characteristics or society as the subject under investigation (Hanifah, 2016). Qualitative research is the process of knowing and understanding in detail in research that explains social or human problems according to the informant's perspective and study behavior in a natural setting (Nababan, 2017). There are two characteristics, namely narrative or descriptive data, not in numbers; qualitative research does not have absolute rules in processing and analyzing data (Gumilang, 2016). Meanwhile, for taking respondents, the purposive technique. This sampling technique is determined based on specific considerations (Sugiyono, 2016).

In this study, it was determined directly the respondents to be used, namely the leader of Cipatat Kolot societies, namely Abah Sacin. The chief of societies is gathered because Abah Sacin can distribute and explain Nyi Pohaci value from the leader's perspective. Another reason is that Abah Sacin is the perpetrator who continues ritual and behavior, which is regarded with Nyi Pohaci as they believe from their ancestor. Even Abah Sacin is the leader of societies who have a task from their previous generation for pursuing and embedding it in the community and their family. Although some societies have neglected this belief, the leader continues to preserve it through their life view and temper. To obtain data in the field, three methods use are observation, in-depth-interview, and documentation. Observation must be released to view the real activity of Abah Sacin, which refers to Nyi Pohaci and the location of Cipatat Kolot societies, and the condition of their culture and tradition. Another collecting way data are in-depth interviews were conducted with key personnel, including the Cipatat Kolot Community Head. In this interview, the researcher raises some of the questions, including Nyi Pohaci based on some proverb language traditional and beliefs connected to a human's body and soul. Paddies are deemed Dewi Sri as part of the human body because Dewi Sri as rice has contributed to encouraging our body function and soul.

The other is to demand Abah Sacin to explain the connection of Nyi Pohaci and the ecology environment because Nyi Pohaci can live life like a person's life. Farmer rekindles Nyi Pohaci, and Nyi Pohaci lives the human, which means that the natural environment, Nyi Pohaci, and humans must be linked together. It can continue to know about culture and tradition in Nyi Pohaci belief for preserving this tradition in young ages. Besides, the researchers try to ask Abah Sacin about agriculture-friendly environments such as applicate organic manure rather than factory manure and a linkage between them. Once the data has been gathered from numerous sources, including data from in-depth interviews, observation, and documentation, the overall data is analyzed using a triangulation approach. 
Sugiyono (2016) states that in qualitative research, data is obtained from various sources. Using various data collection techniques (triangulation), information is carried out continuously until the data is saturated. Meanwhile, triangulation is part of the credibility test. In this, credibility testing is used to check data from various sources in various ways and at multiple times. Data credibility testing is one of the strengths of qualitative research. This is based on determining whether the findings obtained are accurate from the point of view, participant researchers, or readers (Creswell, 2011). In this research, the mixing of several sources of data such as in-depth-interview, observation, and documentation can mention as valid data.

\section{FINDINGS AND DISCCUSIONS}

Environment, culture, and the connection Nyi Pohaci in human

Local paddies are the main sources of food and varieties that must be conserved. Local paddies in Abah Sacin as leader Cipatat Kolot have vanished in the environment. Some local paddies have not been cultivated due to loss from the ground. Paddies and human paddies are integrated. Abah Sacin as leader of Cipatat Kolot, believes that paddies are portrayed as Nyi Pohaci or Dewi Sri. As Nyi Pohaci, they view that the human must appreciate paddies. Dewi Sri in Sundanese, Java, and Bali traditions deem that Dewi Sri is the goddess of paddies which is the most respected (Nastiti, 2020). It triggers to invite the human must respect to Dewi Sri, and the human immediately honors the paddies (Wahyuni, 2019). Abah Sacin as chief of customary societies, reveal that paddies are envisaged as the goddess of Sri Pohaci have related to the body and soul of a human. The local people conserve local paddies because they reliance that humans and paddies are related. As humans, people must respect nature, typically paddies, because there is a soul in paddies, and humans can't survive without eating rice. Abah Sacin has a perspective locally linked to the goddess of Sri. Words or terms that describe Cipatat Kolot's philosophy can see in Table 1 below.

Table 1. Proverb of paddies based on Cipatat Kolot viewing (Sources: inteview abah Sacim 24 Agustus 2020)

\begin{tabular}{llll}
\hline No & Local Language & Indonesia Language & English Language \\
\hline 1. & $\begin{array}{l}\text { Sri anu ngahirupken } \\
\text { urang }\end{array}$ & Sri yang menghidupkan kita & Sri who life human \\
2. & $\begin{array}{l}\text { Sri anu dihirupkan } \\
\text { deui ka urang }\end{array}$ & $\begin{array}{l}\text { Sri yang dihidupkan lagi } \\
\text { oleh kita }\end{array}$ & Sri is lived again by human \\
$\begin{array}{l}\text { Sri eta ayak dibadan } \\
\text { urang }\end{array}$ & Sri ada dibadan kita & Sri is placed in human body \\
$\begin{array}{l}\text { urang ayak dibandan } \\
\text { sri pohaci }\end{array}$ & Kita ada dibadan Sri Pohaci human is placed in Sri Pohaci \\
\hline
\end{tabular}

Paddies in the Abah Sacin perspective are linked to Dewi Sri or Nyi Pohaci goodness. He believes that there is Nyi Pohaci soul in paddies. As a consequence, a human must be respected for paddies. Abah Sacin call paddies as Sri. Paddies have a role in enlivening humans because humans need fundamental necessities from the paddies. A human can't pursue life without consuming paddies and rice. Besides that, paddies must be cultivated again by a human. The seed of paddies can be produced when human-plant it on the surface of the land. There is a strong relationship between nature (paddies) and humans that the sources come from tradition and culture and people's faith.

Nyi Pohaci in Sundanese tripe has cultural value and tradition because people have conducted it nowadays which the behavior have released it before in the last generation recently. The table shows that Cipatat Kolot has a traditional heritage from their forefather, from a proverb's language. It can be categorized as a tangible culture. The five types of intangible local wisdom are thimble, parables, devices, and poetry (Nesi et al., 2019). Abah Sacin as leader of Cipatat Kolot, has received the proverb from there for the father to describe Nyi Pohaci and its relation to human behavior. The words are transferred orally without paper or documented. The proverb continues to 
humans' behavior because it is not just orally. However, the action can be viewed in this finding where Paddies as the goodness of Sri have linkage to the human perspective. The proverb, which is connected to Sri and soul, and the human body, can be seen in Table 2 below.

Table 2. The proverb show the connection of human body and Dewi Sri (Sources: inteview abah Sacim 24 Agustus 2020)

\begin{tabular}{|c|c|c|c|}
\hline No. & Local Language & Indonesia Language & English Language \\
\hline 1. & $\begin{array}{l}\text { Akar sia jadi naun jadi akal ning } \\
\text { manusia }\end{array}$ & $\begin{array}{l}\text { Akar kamu (Sri) jadi } \\
\text { apa, jadi akal manusia. }\end{array}$ & $\begin{array}{l}\text { What is your root (Sri), It become } \\
\text { human mind }\end{array}$ \\
\hline 3. & $\begin{array}{l}\text { Salumpir sia jadi naun jadi pikiran } \\
\text { ing manusia }\end{array}$ & $\begin{array}{l}\text { Daun malai kamu jadi } \\
\text { apa, jadi pikiran } \\
\text { manusia. }\end{array}$ & $\begin{array}{l}\text { What are your panicles leaves, It } \\
\text { become human think }\end{array}$ \\
\hline 6. & $\begin{array}{l}\text { Gagang sia jadi naun jadi gagang } \\
\text { nyawa manusia, (nafas ka luhur } \\
\text { ka handap). }\end{array}$ & $\begin{array}{l}\text { Tangkai malai kamu jadi } \\
\text { apa (Sri), jadi nyawa } \\
\text { manusia. }\end{array}$ & $\begin{array}{l}\text { What are your Stump (Sri), It a part } \\
\text { of human life }\end{array}$ \\
\hline 7. & $\begin{array}{l}\text { Isi sia jadi naun, jadi rupa, jeng } \\
\text { jadi tenaga. }\end{array}$ & $\begin{array}{l}\text { Isi kamu jadi apa, jadi } \\
\text { rupa dan jadi tenaga dan } \\
\text { jadi kebaikan }\end{array}$ & $\begin{array}{l}\text { What are your content (Sri), It a part } \\
\text { of human face and human power }\end{array}$ \\
\hline 8. & $\begin{array}{l}\text { Sri kuning ayak sumsum jeng } \\
\text { balung, sri bereum ayak darah } \\
\text { jeng daging, sri ketan (urat), sri } \\
\text { hejo (dibadan urang ayak } \\
\text { hamperu), sri hedeung (diawak } \\
\text { urang ayak bulu). Jadi sri cukup } \\
\text { dibadan sri, sri ayak dibadan } \\
\text { urang. Jadi sri ngahiji jeng urang. }\end{array}$ & $\begin{array}{l}\text { Sri kuning ada sumsum } \\
\text { dan balung, sri merah } \\
\text { ada daging pada badan } \\
\text { manusia, sri ketan ada } \\
\text { bulu pada badan } \\
\text { manusia, sri hijau ada } \\
\text { empedu pada badan } \\
\text { manusia, jadi Sri (padi) } \\
\text { cukup dibadan Sri, Sri } \\
\text { ada dibadan kita, jadi Sri } \\
\text { bersatu dengan badan } \\
\text { kita. }\end{array}$ & $\begin{array}{l}\text { Sri kuning has marrow and bones, } \\
\text { Sri merah has meat on the human } \\
\text { body, Sri glutinous rice has hair on } \\
\text { the human body, Sri Hijau has bile in } \\
\text { the human body. Meaning that, Sri } \\
\text { (rice) is sufficient in Sri's body, Sri is } \\
\text { in our body, Sri is united with the } \\
\text { body we. }\end{array}$ \\
\hline
\end{tabular}

Table 2, which has been aforementioned, indicates that Abah Sacin describes that paddies or Sri is mixed and created part of the human body, including the skin and hair. There is heavy relation between the part of paddies and the human part of bodies. Paddy's is depicted as the goodness of Sri, which part of the body Sri or paddies is a part of the human body. Some paddies comprise root, stump, left, paddies panicle, and grain of paddies. Each of those parts has contributed to creating all of the human body of the part. The root of paddies is a created mind of the human (brain system). It makes humans can observe and think.

Furthermore, in Abah Sacin perspective, paddies are split based on color, encompassing white, red, black, and green. The sorts of paddies contribute to creating the human body. From the local language above can interpret deeply that paddies have mixed into our body. For example, Sri Kuning can be categorized as white paddies. It has linked to create marrow and borne oh human. They trust that sum-sum and return are made from white paddies like Sri Kuning.

Other paddies are red paddies, which have connected to our blood and meat. Red paddies have bolstered to safe blood and meat of societies. The other paddies, like the Ketan paddies, must be related to the veins of humans. The character of sticky rice paddies is like glue and tendon, which means that veins are made by Ketan paddies when the people consume them. Besides that, when the sorts of paddies are green in color, they believe that they refer to humans' bile. The perspective continues on behavior where Cipatat Kolot societies consume some rice like red, black, and white. The reason for this can be related to the people's pattern for rice consumption. Each kind of rice is different for nutrient-based in color. Each type of that paddies has a strong aspect compare to other paddies. The life philosophy about that link to consumption pattern of a leader like eating some rice at the same time. This principle of making people must cultivate more than one kind of paddies in one period. Scientifically, each of the paddies contains specific nutrients based on color. Pigmented 
rice, such as brown rice and black rice, contains several bioactive components, such as flavonoid compounds that can act as antioxidants (Anggraini et al., 2017).

Red and black rice have antioxidant activity, which can be valuable for protecting humans from diabetes and cardiovascular (hypertension \& arteriosclerosis) (Arifin et al., 2019). (Abdullah, 2017) reveals that red and black rice also possess high nutrients like anthocyanins, which rode as sources of antioxidants and minerals useful for health. Antioxidants protect the human body from free radicals through fender electrons to free radicals (Azis et al., 2015). Also, fiber food content in black rice can bolster prebiotic growth for prebiotic bacteria (Wijayanti, 2017). According to Sumartini (2018), farmers are less focused on red rice cultivation, mostly brown rice, which contributes to health than white rice. It means that variations in rice consumption can create energy and human health in Cipatat Kolot. Because the rice philosophy shows that the leader of Cipatat Kolot applies healthy consumption, in this finding, local people have conveyed that Sri is in our body. Sri has been part of our body, and our body has been part of Sri's body.

The perspective refers to human without conducting cruelty to paddies look like the human is banned to behave abusively to another human (Hertanto, 2013). It is encouraged that women are represented as Dewi Sri, in which the part of the body are created by paddies (Azhima et al., 2020). However, Dewi Sri's faith has eroded because the people don't understand crusty Dewi Sri like when they plant the paddies and harvest paddies that the people generally worship to Dewi Sri but nowadays they adore God (Ardini, 2018). From that proverb of language contribute some another aspect like culture, religion, and ecology of meaning. The language has content several values orally, but it can be identified as behavior to realizing it in real action from intangible knowledge. In Abah Sacin perspective, Dewi Sri or Nyi Pohaci is deemed as goodness. It has impacted on thinking of societies to perceive that Nyi Pohaci is portrayed as paddies. Mudiyono and Wasino (2015) said that societies believe that paddies come from Nyi Pohaci through myth, some region the name of Dewi Sri is varied such as in Sundanese, people call it Nyi Pohaci, in Madura people, have known it as Retna Dilangan and in Kalimantan people recognize it as Pare.

Directly, the faith and culture implied in their forefather must be affected to humans must behave friendly without act abrasively to Nyi Pohaci or paddies. The impact is that this tradition's connection to the environment can be viewed in which humans and paddies as nature are mutually beneficial, which means that humans need nature like paddies. There is mutual relation when humanplant the paddies. When Abah Sacin conveys that "paddies or Sri is enlivened again by human and Sri enlive human" have social and ecological meaning. In the environment system, humans as a social system include technology, attitude, and modification of way to rekindle earth can be categorized as a social system. Nature can be viewed as several values when humans manage and exert, and tillage the soil to fulfill human necessities. As humans don't conduct an action in nature, humans' track record can't be identified. In religion, it can be mentioned as Khalifah or the leader of nature, which God has determined. When social and ecological have created, it refers to pursue agriculture as a basic livelihood of people, and it impacts to conserve agriculture as a venue for human life.

Nyi Pohaci has been portrayed as the goddess of paddies to guarantee that preserving agriculture because they believe that farming behavior can continue the human belief about the existence of the Sri goddess in local farmers. Despite Nyi Pohaci's myth, it creates people's mindset to apply Nyi Pohaci in farm action. Another impact is to create a new farmer to pursue agriculture behavior where the young generation has avoided this valuable sector. Even farming work deem as low social status and increases destination as people involved in farming. Conversely, in local people, typically in Cipatat Kolot, people still use farming as the main source of their life. It is a clue that Nyi Pohaci values have been effect indirectly by their genuine attitude. Sumarlina et al. (2018) reveal coherence between agriculture and Nyi Pohaci because agriculture is linked to some activity, including soil tillage, cultivating, and harvesting. Even Nyi Pohaci can increase the literate of human, especially student, when Nyi Pohacy stories use in learning because Nyi Pohaci stories have some value, including Dewi Sri or Nyi Pohaci is the mother of soil which a place for cultivating the plant for human need and increase literate in ecology as well as respect to soil (Wahyuni, 2019).

Abah Sacin has conveyed that human relation and nature can be identified when Cipatat Kolot's leader has a perspective that humans enlive Sri or Nyi Pohaci as a goddess, which is pictured as paddies. Human action is a natural behavior to manage the landscape and preserve the function of 
the environment for human life. Liu et al., (2020) reveal that it is bidirectional where human attitude and behavior alter the environment. The changing environment results in a change of human traits to nature. Suyud et al. (2020) reveals that human behavior depends on several factors, including attitude, behavior, awareness, and nature knowledge. Human behavior can be viewed as an attitude process that has been passed because the behavior can be looked at as people have the intention of behavior. It must be encouraged by awareness and knowledge, as humans have high awareness and knowledge about the environment's function to be protected, human act friendly environment further. Abah Sacin in Cipatat Kolot perceives that human has to adjust their action not to alter the environment like part of the paddies. For illustration, local paddies like Sri Kuning and Raja Wesi have fur. Abah Sacin said that as women don't have hair in their head, they look ugly despite that human is beauty. It is a shame with the paddies, as humans omit Bulu from paddies' skin, the paddies will be ugly.

The statement indicates that humans are prohibited from transforming or altering paddies because it creates the paddies look worsen. Unfortunately, several local paddies have an extinction from nature. Humans must create harmony concerning nature because nature bolsters humans' sustainable life through the myth of Nyi Pohaci (Anggraini et al., 2017). Rice fields must be identified as prohibitions to cultivated. The ban on planting rice on Mondays is due to the local people respecting Nyi Pohaci, who currently believes that women perform masturbation. In this day, cultivating can't be held. However, the prohibition of the day can continue at another time. While, on Sunday, people can plant the paddies (Supriatna \& Nugraha, 2020). Abah Sacin reveals some sort of local paddies, including Sri Kuning, Raja Wesi, benter, kuwi, keten hiding, gadok, sticky rice bogor, sticky rice holes (extinct). However "ketan hideung" variety can distinguish its parts of rice; all are black. The height of the rice is very high. It reaches as high as humans.

The length of the local rice stalk reaches $40-50 \mathrm{~cm}$. The vanishing of paddies as a form that tradition can't withstand to culture and social perturbances. The extinction of paddies impacts human needs. However, local rice began to disappear. On one side, local people like Urug societies and Cipatat Kolot have a tradition like "mipit amit ngala kudu menta". The meaning of this word is picker must admit. For Instance, when planting the paddies, a human must permit God to create the creature and nature. The tradition can impact to adjust human trait not to ravage the nature environment (Irfani et al., 2020). Besides that, human interaction with nature can be identified because the human's role is a leader in nature. Humans must rekindle nature like soil. Cultivating paddies is the example to relife soil or land and make humans a manager in nature. In this, when people believe that Nyi Pohaci as a goddess impacts human function in nature. It connects to religion, where humans as Khalifah in nature. As Khalifah, humans must manage the soil, water, forest, and eluding nature from ravaged. There is some process to indicate that seed revamps to plant. Therefore, humans tire to release abrasive temper to nature for creating some damaged.

Nyi Pohaci, soil fertility, and agriculture

The belief in Nyi Pohaci is proof that indigenous people must respect nature. Nature and human is a mutual need. Humans may not survive because of the destruction of nature and rice fields because they are part of Nyi Pohaci. It refers to faith where the human damaged nature. It has an impact on hearth Nyi Pohaci. The belief affects their behavior to manage the land and release agriculture, but the farming must be social ecology. One relation is Nyi Pohaci deem as the goddess of fertility in agriculture (Nastiti, 2020). The community conserves the soil to ensure and protect soil nutrients from extinction. It includes organic behavior, which is the soul of the local community. The temper can be mentioned as low internal Input of agriculture. Indigenous knowledge action has mixed organic and inorganic manure. Even the usage of an-organic manure is less instead of using organic fertilizers. When organic fertilizer is dominated rather than an-organic manure, agriculture sustainability can be achieved by local people. It is related to the decline in chemical fertilizers' usage and changes it to internal Input without chemistry (Panjaitan et al., 2015).

Methods optimize in using local resources or internal Inputs like the production of organic manure locally. The resources locally include livestock activity. It can be used as a source of the organic output of fertilizer and natural resources that can be encouraged for composting production 
(Nuraini et al., 2015). Struik and Kuyper (2017) remark that sustainability is the power of farmers to continue animal and crop production without deteriorating the environment for economic advantage and social stability. Agriculture sustainability must integrate economic, ecology, and social dimension (Mahmuddin, 2013; Wardie \& Sintha, 2016). Cipatat Kolot Societies have implied behavior locally, like using organic manure to jump paddies production rate. Ibeawuchi et al. (2015) reveal that reducing the usage of an-organic fertilizer can replenish the soil and control pests, weeds, and diseases to create sustainability. It is strengthened that It helps to: 1.) Reduce off-farm inputs, such as synthetic fertilizer, pesticides, and energy (e.g., for water pumps, fuel, crop harvest machinery, storage, processing, Etc.); 2.) Mitigate negative macro-economic externalities (GHG emissions, biodiversity loss, ground and surface water contamination, soil organic matter loss, erosion, degradation, land-use change); and 3.) Ensuring feasible economic benefits at farm level (Von Cossel et al., 2019).

The impact is to raise the social and economic benefits by declining using Input from outside of the local region and refining the environment's quality. To achieve sustainable agriculture, the key of customary societies, namely Nurhasyim in Cipatat Kolot societies, utilizes organic manure. Meanwhile, the implementation of organic fertilizer can reduce the emission rate (Wihardjaka, 2018). The community uses two sorts of fertilizer, including an-organic manure and natural manure. They don't applicate factory fertilizer fully but combining factory fertilizer with organic manure. Urea mix to organic fertilizer, another period of spreading urea fertilizer after cleaning grass or ramet. Local people exert organic matter like goat, cow, buffalo feces for inventing organic fertilizer. People use organic material for the production of fertilizer. Organic fertilizer like goat feces must be burned until produce organic dust fertilizer. The objective is to ensure that fertilizer can be absorbed by soil completely. However, when organic goat feces have not altered to dust, it can demerits because compost fertilizer will not be absorbed. Organic fertilizer is utilized in the land. After planting paddy in rice paddy yield about 20 days, in-organic fertilizers are implied to help paddy growth. The usage of fertilizer relies on the level of soil fertility. Wet paddy land doesn't need to render fertilizer when land in the mountains area is still a virgin area. To decide soil is fertile can exert biological, physical indicator, and chemistry measurement (Griffiths et al., 2018; Huera-Lucero et al., 2020).

\section{CONCLUSION}

Mythology in society is not true, but mythology has educated humans to avoid behaviors that cause damage to the environment. There is a moral value that is contained in making humans not arbitrarily act badly. The indigenous people of Cipatat Kolot have traditions and culture passed down from generation to generation, including life views based on Dewi Sri or Nyi Pohaci Sang Hyang Asri. According to Sachin's brother, the indigenous peoples express traditional personalities that describe local values or values based on Nyi Pohaci's beliefs. They believe that Nyi Pohaci and humans need each other. Humans are in Nyi Pohaci, and Nyi Pohaci is in human bodies. All parts of the human body, starting from human bones, human intellect, human flesh, human form, the hair on human bodies, bile in human stomachs, human minds and minds are formed because of Nyi Pohaci, namely rice consumed by humans. Even the indigenous people distinguish various types of rice colors, which they call Sri and are associated with human body parts such as white Sri, which is related to human bones and Sri red which forms human blood, and Sri is green which forms human bile. This belief is associated with Nyi Pohaci depicted as the goddess of rice, while the rice goddess is a part of human life because people consume rice or rice.

Immediately, humans and ecology have connected because when the people rekindle Nyi Pohaci, the human must conserve and tillage land and care for the environment. After all, the environment, Nyi Pohaci, and people can't be separated. Humans need a domain like land to cultivate rice like Nyi Pohaci. The belief has an advantage where the customary societies hate to ravage the natural environment because they convince that they have hearted Nyi Pohaci Sang Hyang Asri. The other is agriculture friendly for the environment as part of Cipatat Kolot in Abah Sacin perspective and Abah Nurhasim because they exert organic fertilizer for the production of paddies. They also use factory fertilize, but they use it when it needs most and depend on the paddies' condition. As paddies grow correctly, they postpone applicating manure. There are many advantages to the environment 
because organic farming does not damage the soil and has contributed to soil and water conservation because people use organic matter such as manure to improve soil fertility in the long term. In the end, they are maintaining the stability of rice production.

\section{REFERENCES}

Abdullah, B. (2017). Peningkatan kadar antosianin beras merah dan beras hitam melalui biofortifikasi. Jurnal Penelitian Dan Pengembangan Pertanian, 36(2), 91-98. https://doi.org/10.21082/jp3.v36n2.2017.p91-98

Alfarisi, A. S., Firdayani, F. A., Safitri, A. A., Ariyanti, F., \& Pradana, A. B. H. (2019). Mitos dan budaya kaapunan masyarakat Gantung, Belitung Timur di tengah masyarakat globalmulikultural. Buletin KKN Pendidikan, 1(1), 18-22. https://doi.org/10.23917/bkkndik.v1i1.9283

Angeline, M. (2015). Mitos dan budaya. Humaniora, 6(2), 190-200. https://doi.org/10.21512/humaniora.v6i2.3325

Anggraini, T., Dewi, Y. K., \& Sayuti, K. (2017). Karakteristik sponge cake berbahan dasar tepung beras merah, hitam, dan putih dari beberapa daerah di Sumatera Barat. JLI (Jurnal Litbang Industri), 7(2), 123-136. https://doi.org/10.24960/jli.v7i2.3378.123-136

Ardini, Y. W. N. (2018). Upacara menanam padi di Desa Lambeyan Wetan, Kecamatan Lambeyan, Kabupaten Magetan. Haluan Sastra Budaya, 2(1), 105-119. https://doi.org/10.20961/hsb.v2i1.21266

Arifin, A. S., Yuliana, N. D., \& Rafi, M. (2019). Aktivitas antioksidan pada beras berpigmen dan dampaknya terhadap kesehatan. Pangan, 28(1), 11-22. https://doi.org/10.33964/jp.v28i1.416

Azhima, F. F., Priyatna, A., \& Muhtadin, T. (2020). Mitos dan representasi Dewi Sri dalam ritual sinoman upacara adat Mapag Sri di Desa Slangit Kabupaten Cirebon: Kajian Semiotika. Metahumaniora, 10(2), 217-229. https://doi.org/10.24198/metahumaniora.v10i2.25733

Azis, A., Izzati, M., \& Haryanti, S. (2015). Aktivitas antioksidan dan nilai gizi dari beberapa jenis beras dan millet sebagai bahan pangan fungsional Indonesia. Jurnal Akademika Biologi, 4(1), 45-61. https://ejournal3.undip.ac.id/index.php/biologi/article/view/19400

Bikker, A. P., Atherton, H., Brant, H., Porqueddu, T., Campbell, J. L., Gibson, A., McKinstry, B., Salisbury, C., \& Ziebland, S. (2017). Conducting a team-based multi-sited focused ethnography in primary care. BMC Medical Research Methodology, 17(1), 139. https://doi.org/10.1186/s12874-017-0422-5

Creswell, J. W. (2011). Educational research planning: Planning, conducting, and evaluating quantitative and qualitative research. Pearson Education.

Griffiths, B. S., Faber, J., \& Bloem, J. (2018). Applying soil health indicators to encourage sustainable soil use: The transition from scientific study to practical application. Sustainability, 10(9), 1-14. https://doi.org/10.3390/su10093021

Gumilang, G. S. (2016). Metode penelitian kualitatif dalam bidang bimbingan dan konseling. Jurnal Fokus Konseling (Online ), 2(2), 144-159. https://doi.org/10.26638/jfk.218.2099

Hanifah, N. (2016). Teori penerjemahan sebagai dasar pembelajaran penerjemahan: Studi kualitatif etnografi. Cakrawala Pendidikan, 35(2), 254-263. https://doi.org/10.21831/cp.v15i2.8071

Hermawan, A. J. (2013). Interaksi simbolik masyarakat adat Cigugur Kuningan (studi etnografi dalam tradisi seren taun). Jurnal Signal, 1(2). https://doi.org/10.33603/signal.v1i2.680

Hermawan, F. W. (2016). Mitos dan relasi ketidaksadaran masyarakat. Dharmasmrti: Jurnal Ilmu Agama Dan Kebudayaan, 15(28), 91-107. https://doi.org/10.32795/ds.v15i28.62

Hertanto, H. (2013). "Pohaci” sebuah abstraksi karya dari serat Carios Dewi Sri. Greget, 12(2), 196- 
209. http://repository.isi-ska.ac.id/1422/1/509

Heryana, A. (2012). Mitologi perempuan Sunda. Patanjala : Jurnal Penelitian Sejarah Dan Budaya, 4(1), 156-169. https://doi.org/10.30959/patanjala.v4i1.129

Huera-Lucero, T., Labrador-Moreno, J., Blanco-Salas, J., \& Ruiz-Téllez, T. (2020). A Framework to Incorporate Biological Soil Quality Indicators into Assessing the Sustainability of Territories in the Ecuadorian Amazon. In Sustainability (Vol. 12, Issue 7, p. 3007). https://doi.org/10.3390/su12073007

Ibeawuchi, I. I., Obiefuna, C. J., \& Iwuanyanwu, U. P. (2015). Low external input agricultural farming system for the increase in productivity of resource poor farmers. Journal of Biology, Agriculture and Healthcare, 5(2), 109-116. https://www.iiste.org/Journals/index.php/JBAH/article/view/19548

Ihsan, B. (2019). Peran pembelajaran budaya lokal dalam pembentukan karakter siswa Madrasah Ibtidaiyah (MI). MIDA: Jurnal Pendidikan Dasar Islam, 2(2), 1-8. https://doi.org/10.52166/mida.v2i2.1571

Irfani, F., Bahagia, B., Mangunjaya, F. M., \& Wibowo, R. (2020). Character building caring for the environment based on local knowledge in Urug societies Bogor West Java. Tunas Geografi, 9(2), 143-155. https://doi.org/10.24114/tgeo.v9i2.21194

Iswidayanti, S. (2007). Fungsi mitos dalam kehidupan sosial budaya masyarakat pendukungnya (The function of myth in social cultural life of its supporting community). Harmonia: Journal of Arts Research and Education, 8(2), 180-184. https://doi.org/10.15294/harmonia.v8i2.790

Jatnika, A. (2018). Hajat lembur peristiwa ritual kesuburan. Jurnal Seni Makalangan, 5(1), 31-43. https://jurnal.isbi.ac.id/index.php/makalangan/article/view/833

Kusdiwanggo, S., \& Pamungkas, S. T. (2017). Pangheucakan: Elemen bangun budaya padi kasepuhan ciptagelar dengan teknologi lokal yang terancam pupus. Simposium Nasional RAPI XVI, 162-169. http://hdl.handle.net/11617/9516

Liu, Y., Deng, W., \& Peng, L. (2020). Building a Framework of Evaluating Human-Environment Relationships: Considering the Differences between Subjective Evaluations and Objective Assessments. In Sustainability (Vol. 12, Issue 1, p. 167). https://doi.org/10.3390/su12010167

Mahmuddin, M. (2013). Paradigma pembangunan pertanian: Pertanian berkelanjutan berbasis petani dalam perspektif sosiologis. Sosiologi USK, 3(1), 59-75. http://www.jurnal.unsyiah.ac.id/JSU/article/view/10599

Margaretha, R. (2017). Analisis klasifikasi mitos dalam tradisi lisan masyarakat Lampung. JPP (Jurnal Pendidikan Progresif), 7(2), 117-126. https://doi.org/10.23960/jpp.v7.i2.201715

Mudiyono, M., \& Wasino, W. (2015). Perkembangan tanaman pangan di Indonesia tahun 1945-1965. Journal of Indonesian History, 38-45. https://journal.unnes.ac.id/sju/index.php/jih/article/view/18986

Nababan, E. B. (2017). Analisis penelitian kualitatif dengan lima pendekatan (biografi, fenomenelogi, teori grounded, studi kasus, dan etnografi). Jurnal Ilmiah Maksitek, 2(2), 1-7. http://repository2.uph.edu/599/1/Jurnal.pdf

Nadroh, S. (2018). Pikukuh karuhun baduy dinamika kearifan lokal di tengah modernitas zaman. Pasupati, 5(2), 196-216. https://doi.org/10.37428/pspt.v5i2.117

Nastiti, T. S. (2020). Dewi Sri dalam kepercayaan masyarakat Indonesia. Tumotowa, 3(1), 1-12. https://doi.org/10.24832/tmt.v3i1.48

Nesi, A., Rahardi, R. K., \& Pranowo, P. (2019). Nilai-nilai kearifan lokal dalam tradisi lisan takanab: Kajian ekolinguistik. Jurnal Pendidikan Dan Kebudayaan Missio, 11(1), 71-90. http://jurnal.unikastpaulus.ac.id/index.php/jpkm/article/view/138 
Nuraini, A., Yuwariah, Y., \& Rochayat, Y. (2015). Pengembangan produksi pertanian lahan kering dengan sistem Low External Input Sustainable Agriculture (LEISA) di Desa Cigadog, dan Mandalagiri Kecamatan, Leuwisari Kabupaten Tasikmalaya. Dharmakarya: Jurnal Aplikasi Ipteks Untuk Masyarakat, 4(2), 113-118. https://doi.org/10.24198/dharmakarya.v4i2.10037

Panjaitan, E., Indradewa, D., Martono, E., \& Sartohadi, J. (2015). Sebuah dilema pertanian organik terkait emisi metan (a dilemma on organic farming in relation to methane emission). Jurnal Manusia Dan Lingkungan (Journal of People and Environtment), 22(1), 66-72. https://doi.org/10.22146/jml.18726

Rohmana, J. A., \& Ernawati, E. (2014). Perempuan dan kearifan lokal: Performativitas perempuan dalam ritual adat Sunda. Musawa: Jurnal Studi Gender Dan Islam, 3(2), 151-166. https://doi.org/10.14421/musawa.2014.132.151-166

Struik, P. C., \& Kuyper, T. W. (2017). Sustainable intensification in agriculture: the richer shade of green. A review. Agronomy for Sustainable Development, 37(5), 39. https://doi.org/10.1007/s13593-017-0445-7

Sugiyono, S. (2016). Metode Penelitian Kuantitatif, Kualitatif, dan R\&D. Alfabeta.

Sumarlina, E. S. N., Darsa, U. A., \& Permana, R. S. M. (2018). Pemuliaan pangan berbasis naskah mantra pertanian dalam kaitannya dengan tradisi masyarakat kampung Naga dan Baduy. Jumantara: Jurnal Manuskrip Nusantara, 9(2), 69-94. https://doi.org/10.37014/jumantara.v9i2.244

Sumartini, S. (2018). Kajian peningkatan kualitas beras merah (oryza nivara) instan dengan cara fisik. Pasundan Food Technology Journal (PFTJ), 5(1), 84-90. https://doi.org/10.23969/pftj.v5i1.842

Supriatna, R. A., \& Nugraha, Y. A. (2020). Menguak realitas praktik sedekah bumi di Desa Ciasmara Kecamatan Pamijahan Kabupaten Bogor. Jurnal Penelitian Sosial Ilmu Komunikasi, 2(1), 43 59. https://journal.unpak.ac.id/index.php/apik/article/view/1804

Suryani, I. (2014). Menggali keindahan alam dan kearifan lokal Suku Baduy (studi kasus pada acara feature dokumenter "Indonesia Bagus" di stasiun televisi NET.TV). Musawa: Jurnal Studi Gender Dan Islam, 3(2), 179-194. https://doi.org/10.14421/musawa.2014.132.179-194

Suyud, S., Mangunjaya, F. M., Bahagia, B., \& Wibowo, R. (2020). Attitude, knowledge, awarness toward behavior for protecting environment base on Islamic view. Spatial: Wahana $\begin{array}{lllll}\text { Komunikasi Dan Informasi } & \text { Geografi, }\end{array}$ http://journal.unj.ac.id/unj/index.php/spatial/article/view/16072

Von Cossel, M., Lewandowski, I., Elbersen, B., Staritsky, I., Van Eupen, M., Iqbal, Y., Mantel, S., Scordia, D., Testa, G., Cosentino, S. L., Maliarenko, O., Eleftheriadis, I., Zanetti, F., Monti, A., Lazdina, D., Neimane, S., Lamy, I., Ciadamidaro, L., Sanz, M., ... Alexopoulou, E. (2019). Marginal agricultural land low-input systems for biomass production. Energies, 12(16), 1-25. https://doi.org/10.3390/en12163123

Wahyuni, L. (2019). Konstruksi agriliteracy melalui dongeng "Dewi Sri." Belajar Bahasa: Jurnal Ilmiah Program Studi Pendidikan Bahasa Dan Sastra Indonesia, 4(1), 93-104. https://doi.org/10.32528/bb.v4i1.1869

Wardie, J., \& Sintha, T. Y. E. (2016). Analisis sustainabilitas usahatani padi pada lahan gambut di Kabupaten Kapuas. Agric, 28(1), 87-94. https://doi.org/10.24246/agric.2016.v28.i1.p87-94

Wihardjaka, A. (2018). Penerapan model pertanian ramah lingkungan sebagai jaminan perbaikan kuantitas dan kualitas hasil tanaman pangan. Pangan, 27(2). https://doi.org/10.33964/jp.v27i2.376

Wijayanti, M. I. (2017). Kualitas yoghurt sinbiotik sari beras hitam (Oryza sativa L.) dengan variasi susu skim [Universitas Atma Jaya Yogyakarta]. http://e- 
12 - Harmoni Sosial: Jurnal Pendidikan IPS

journal.uajy.ac.id/11243/1/JURNAL.pdf

Yunarti, Y., \& Rahmadani, W. (2017). Nilai edukasi mitos dan relevansinya dengan penanaman nilai pada keluarga Minangkabau kontemporer: Tinjauan Awal. Jurnal Antropologi, 19(1), 55-65. https://doi.org/10.25077/jantro.v19.n1.p55-65.2017

Yusanti, E. (2019). Fungsi mitos dalam kehidupan masyarakat Pulau Temiang, Jambi. Jurnal Totobuang, 7(1), 171-181. https://doi.org/10.26499/ttbng.v7i1.141 